\begin{tabular}{rr} 
çaḡdaş & Yaratıci Drama Dergisi 2018, 13(1), 19-36 \\
drama & www.yader.org \\
\hline
\end{tabular}

\title{
Hidroelektrik Santrallerin Çevresel Etkilerinin Yaratıcı Drama Yöntemiyle İşlenmesi
}

\begin{tabular}{|c|c|c|}
\hline \multicolumn{3}{|r|}{ Aylin Çalışkan ${ }^{1}$} \\
\hline Makale B & & Öz \\
\hline DOI: 10.216 & der.2018.002 & \multirow{9}{*}{ 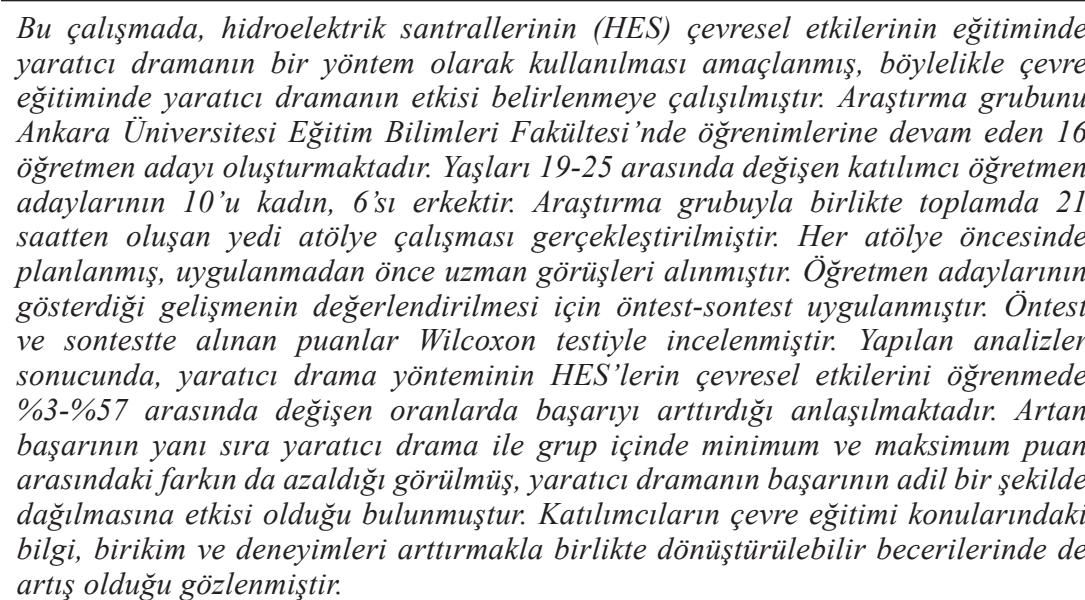 } \\
\hline Makale Geç & & \\
\hline Gelis tarihi & 9.01 .2017 & \\
\hline Kabul & 10.05 .2017 & \\
\hline Anahtar Sö & & \\
\hline Yaratıcı dra & & \\
\hline Çevre eğitim & & \\
\hline Çevresel etk & & \\
\hline Hidroelektri & aralleri & \\
\hline
\end{tabular}

\section{Processing of Environmental Impacts of Hydroelectric Power Plants by Creative Drama Method}

\begin{tabular}{ll}
\hline Article Info \\
\hline DOI: $10.21612 /$ yader.2018.002 \\
\hline Article History & \\
Received & 9.01 .2017 \\
Accepted & 10.05 .2017
\end{tabular}

Keywords

Creative drama

Eviromental education

Enviromental impact

Hydroelectricity power plant

\begin{abstract}
This study aimed the use of creative drama as a method at environmental education and in particular in the education of the environmental effects of hydroelectric power plants (HPP) and thus the effect of creative drama in environmental education. The research group of the study consists of 16 teacher candidates from the Faculty of Educational Sciences of Ankara University. 10 of the participant teacher candidates are female and 6 are male, and their aged differs between 19 and 25 years. Seven workshops those have totally 21 hours have been carried out with the research group. Every workshop is planned and expert opinions were received ahead of schedule. In order to determine the development of teacher candidates pretest and posttest were applied to participants. The validity of the tests used in this evaluation has been ensured by expert opinions. Scores in the pretest and posttest were examined by the Wilcoxon test. As a result of the analyzes made, the creative drama method has a success ranging from $3 \%$ to $57 \%$ in learning the environmental effects of HPPs. In addition to improving success, it also reduces the difference between the minimum and maximum points within the group. It was found to have an effect on the fair distribution of success. Participants have increased their knowledge, experience and practise in environmental education. However, there is also a considerable increase in the transferable skills.
\end{abstract}




\section{Giriş}

Tarih boyunca barajlar çok farklı işlevleri yerine getirmek için inşa edilmiştir. Bunlardan ilki su teminidir. Çeşitli ebatlardaki setlerle inşa edilen baraj gölleri, sadece içme suyu temini için değil ayrıca tarım arazilerinin sulanması için de kullanılmıştır. Barajların önemli bir diğer işlevi ise taşkın kontrolüdür. Uzun yıllar aynı yatak içinde akıntılarını sürdüren akarsular, belli aralıklarla oluşan sağanak yağışlar ve kar erimeleriyle taşabilmektedir. Taşkın ve sel riskini en aza indirmek için akarsuların ıslahı ve baraj inşası gündeme gelmektedir. 19. yüzyılın başlarında Sir Charles Algernon Parsons'un türbini icat etmesinin ardından barajlar elektrik üretimi için de kullanılmaya başlamıştır (Parsons, 2012). Bir setin gerisinde hapsedilen suyun yarattığı hidrostatik basıncın kullanımına dayanan bu tarz elektrik üretimi hidroelektrik santrallerinin (HES) ortaya çıkmasına neden olmuştur. İlk HES, İngiltere Northumberland'ta William George Armstrong tarafindan inşa edilmiştir (McKenzie, 1983). Özellikle 20. yüzyılla birlikte HES'ler ve onlara bağlı oluşturulan baraj gölleri sayısında bir patlama yaşanmıştır. Günümüzde baraj göllerinin bir diğer işlevi ise eğlendinlen etkinliklerine ev sahipliği yapmalarıdır. Su kütleleri insanların kendilerini psikolojik olarak rahat hissettikleri yerlerin başında gelmektedir. Özellikle büyük şehirlere yakın olan baraj gölleri, etrafının düzenlenmesiyle yeşil alanlara, oyun alanlarına dönüştürülmekte ve insanların kullanımına açılmaktadır.

Barajların yapılmasında en önemli iki etken su temini ve enerji üretimidir. Su yaşam için gereken yegâne şarttır. Su olmadığında yaşam da olmamaktadır. İnsanların kalabalık şehirler inşa etmesiyle birlikte temiz su sorunu çözülmeyi bekleyen en önemli sorunlardan biri olmuştur. Diğer yandan enerjiye duyulan gereksinim her geçen gün artmaktadır. Ülkelerin kullandığı enerji miktarı, gelişmişliklerinintemelölçütüolarakkabulgörmektedir. Dünyaüzerindekullanılanenerjikaynaklarının büyük bir bölümü (\%75’i) çevresel sorunlara yol açan fosil yakıtlardan sağlanmaktadır (British Petroleum, 2009). Fosil yakıtların neden olduğu pek çok çevresel felaketin önlenmesi, sorunların çok geç olmadan çözülmesi için yenilenebilir ve temiz enerji kaynaklarının kullanımı önem kazanmıştır. Başta Birleşmiş Milletler ve Avrupa Birliği (AB) olmak üzere uluslararası kuruluşlar temiz enerji kaynakları için ciddi planlar yapmaktadır. Artan enerji tüketimini karşılamada fosil yakıtlar yerine yenilenebilir enerji kaynakları kullanımı giderek yaygınlaşmaktadır. Bu anlamda, Birleşmiş Milletler 2050 yılına kadar sera gazı emisyonlarının \%50 oranında düşürülmesini hedeflerken, AB 2020 yılına kadar enerjinin \%20'sinin yenilenebilir enerji kaynaklarından sağlanmasını hedeflemektedir. AB bu noktada belirli standartlarda yenilenebilir enerjiyi teşvik ederken, gelişmiş bir çevre mevzuatını da uygulamaktadir (Ayas, 2010).

HES'ler fosil yakıtlara alternatif, temiz ve yenilenebilir bir enerji kaynağı olarak görülmektedir. Bununla birlikte HES kurulumu için gereken baraj yerinin coğrafi özellikleri çok önemlidir. Barajın kurulacağ1 yerin iklimi, bitki örtüsü, jeolojik ve ekolojik özellikleri dikkate alınmadığında ciddi ekonomik ve çevresel sorunlar ortaya çıkmaktadır. Bunların yanı sıra baraj yapımı için tercih edilen bölgenin tarihi ve kültürel dokusunun da göz önünde bulundurulması gerekmektedir. HES'lerin fayda-maliyet analizlerinin bütüncül bir bakış açısıyla yapılması önemlidir. Yenilenebilir bir enerji kaynağı olup olması tamamen planlı yapılmasına bağlıdır (Ayas, 2010; Yılmaz, Ali, Zeybek ve Mutlu, 2012; Yurtseven, 2011).

Plansız yapılan HES'ler doğayı tahrip ederken hiçbir getirisi olmayan işletmeler kurulmasına neden olmaktadır. Çevre eğitiminde önemli tartışma konularından biri olması da bu karmaşık 
durumundan kaynaklanmaktadır. Çevre eğitiminde kullanımı anlamlı sonuçlar veren yaratıcı drama (McNaughton, 2004), çağdaş eğitim bilimcilerin üzerinde oldukça ilgiyle durduğu, eğlenerek öğrenmeyi diğer bir deyişle oyunla öğrenmeyi hedefleyen bir öğretim yöntemidir. Öğrencilerin kavram ve durum geliştirmesi, sosyal durumları analiz etmesi, toplumsal problemlerin çeşitli boyutlarını görüp çözüm geliştirmesi ve liderlik - yöneticilik özelliklerinin ortaya çıkarılmasında oldukça etkilidir. "Yaratıcı drama; bir grupla ve grup üyelerinin yaşantılarından yola çıkarak, bir amacın, düşüncenin, doğaçlama, rol oynama (rol alma) vd. tekniklerden yararlanarak canlandırılmasıdır. Bu canlandırma süreçleri deneyimli bir lider/eğitmen eşliğinde yürütülürken kendiliğindenliğe (spontaniteye), şimdi ve burada ilkesine, -mış gibi yapmaya dayalıdır ve yaratıcı drama, oyunun genel özelliklerinden doğrudan yararlanır." (Adıgüzel, 2014, s. 10).

$\mathrm{Bu}$ çalışma kapsamında öğretmen adaylarının katıldığı bir grupla yaratıcı drama yöntemi kullanılarak akarsulara bağlı gelişen çevre koşulları ve ekosistemler, akarsuların bölgesel ve küresel önemi konusunda bir süreç yürütülmüştür. HES'lerin olumlu ve olumsuz yönleri yaratıcı dramanın rol oynama, doğaçlama, canlandırma ve diğer teknikleriyle yapılandırılmıştır (Adıgüzel, 2014; Di Pietro, 1987; Donato ve McCormick, 1994; Lukinsky, 1990; Mezirow, 1990; Miccoli, 2003; Schön, 1991; Via, 1976; Wagner, 1976; Windsor, vd., 2011). HES'lerin çevresel, kültürel etkilerinin yaratıc1 drama yöntemiyle öğretilmesinin daha etkin ve kalıcı bir öğrenme sürecini beraberinde getirdiği gözlenmektedir. Yaratıcı dramanın kalıcı öğrenmeye etkisi, çevre eğitiminde sürdürülebilirlik açısından önemlidir (McNaughton, 2004).

Çalışma hedefler; içerik; yaklaşım, yöntem, teknik ve değerlendirme süreci olarak temel dört aşama olarak planlanmıştır (Şekil 1) (Demirel, 2014, ss. 13-14; Üstündağ, 2000, ss. 1-3).

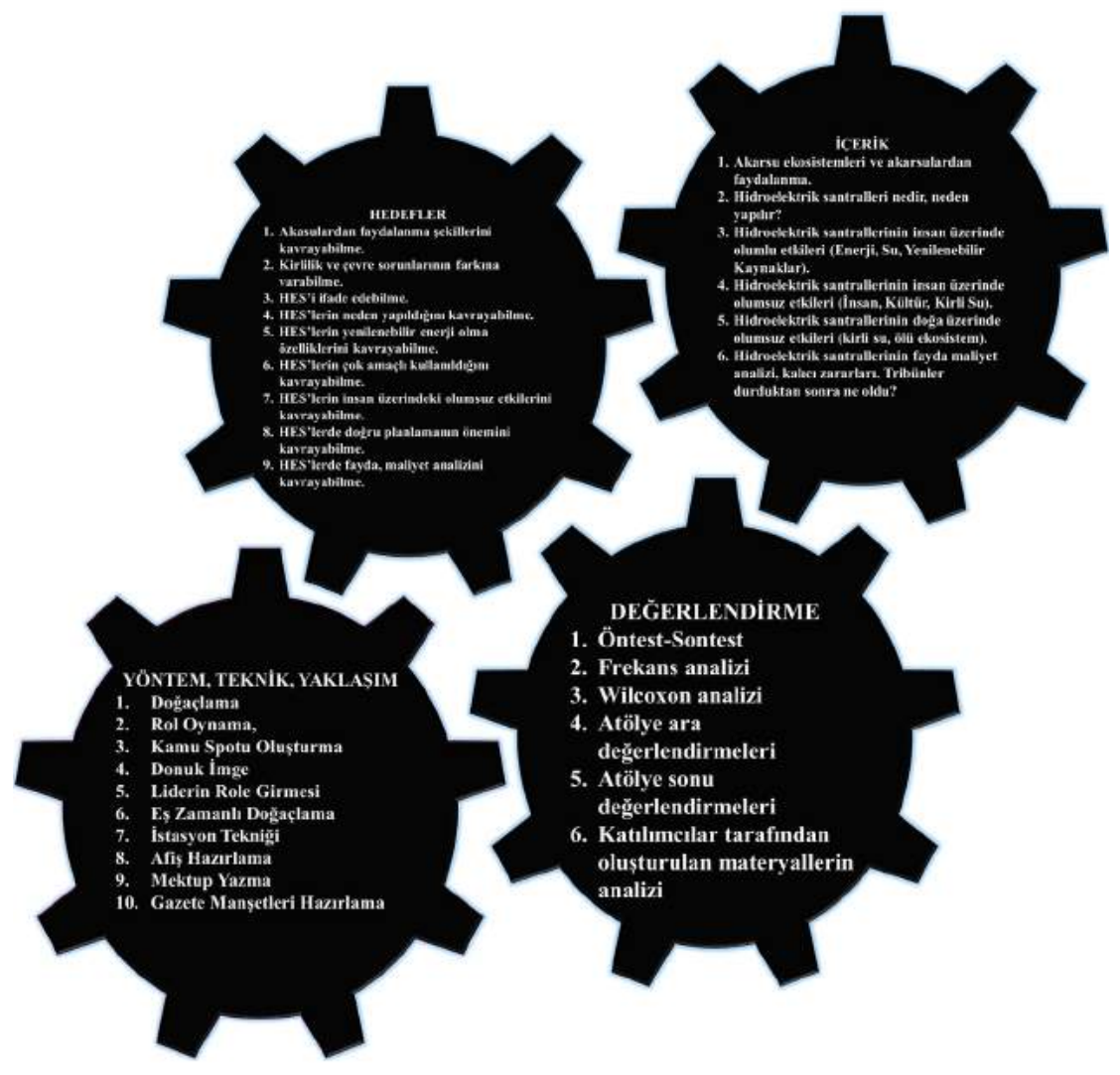

Şekil 1. Çalışma planının temel bileşenleri. 


\section{Yöntem}

\section{Araştırma Modeli}

Bu çalışma kapsamında nicel araştırma yöntemlerinden biri olan deneysel araştırma modeli kullanılmıştır. Deneysel araştırma modeli, araştırmacının kontrolündeki değişkenler arasındaki neden-sonuç ilişkilerinin test edildiği bir araştırma alanıdır. Bu amaçla gözlenmek istenen verilerin üretilmesi ilkesine dayanmaktadır (Büyüköztürk, 2001; Karasar, 2012). Deneklerin yaratıcı drama süreci sonucunda gelişimlerinin gözlenmesi için deneysel araştırma modellerinden tek grup öntestsontest deseni uygulanmıştır. Bu desende rastlantısal olarak seçilen tek bir çalışma grubuna uygulama öncesi öntest ve uygulama sonrası sontest gerçekleştirilmiştir. Her iki teste de aynı ölçme aracı kullanılmıştır. Bu model karşılaştırma yapmayı kolaylaştırmaktadır. Deneklerin süreç sonundaki durumunu niceliksel olarak vermesi de değerlendirmeyi kolaylaştırmaktadır.

\section{Çalışma Grubu}

Çalışmanın uygulandığı grup, Ankara Üniversitesi Eğitim Bilimleri Fakültesi Sosyal Bilgiler Öğretmenliği programına kayıtlı 16 öğrenciden oluşmaktadır. Rastlantısal seçilen 10 kadın ve 6 erkekten oluşan grupta 1 kişi 19 yaşında, 10 kişi 20 yaşında, 4 kişi 21 yaşında, 1 kişi 25 yaşındadır. Tamamı Sosyal Bilgiler Öğretmenliği 2. sınıf öğrencisi olan grup Genel Fiziki Coğrafya, Genel Beşeri ve Ekonomik Coğrafya, Türkiye Fiziki Coğrafyası, Ekonomi, Sosyoloji, Eskiçağ Tarihi ve Uygarlığı gibi insan faaliyetlerinin çevresel etkilerini öğrenebilecekleri dersler almışlardır. Aynı zamanda akarsular ve çevresel etkileri konusunda da hazır bulunuşlukları yaratıcı drama çalışmasının amaçlarına uygundur. Katılımcıların öğretmen adayı olmasının bir diğer önemli getirisi, çevre eğitimi konusunda kendilerini geliştirmelerinin dikkate değer bir motivasyon kaynağı olmasıdır. Ayrıca öğretmen olduklarında ortaokul 5. 6. 7. 8. sınıf öğrencilerine çevre, ekosistem, insan ve doğa konularını kapsayan dersler vereceklerdir.

\section{Veri Toplama Araçları}

\section{Öntest-Sontest}

Çalışma kapsamında yaratıcı dramanın katılımcılar üzerinde etkisini görebilmek için öntest ve sontest ölçme yönteminden yararlanılmıştır. Öntest ve sontest soruları her bir atölyede araştırmacılar tarafından belirlenen kazanımlar göz önünde bulundurularak hazırlanmıştır (Şekil 2). Katılımcıların gelişimini değerlendirmek için ilk etapta 40 adet çoktan seçmeli soru hazırlanmıştır. Soruların tamamı bilgiyi ölçmek üzere tasarlanmıştır. Soruların geçerliliği üç farklı uzmandan alınan görüşler doğrultusunda sağlanmıştır. ${ }^{3}$ Uzman görüşleri doğrultusunda sorularda gerekli düzeltmeler, değişiklikler gerçekleştirilmiştir ve uzmanlar tarafından çıkarılması istenen 5 adet soru testten çıkarılmıştır. Uzman görüşleri doğrultusunda yeniden yapılandırılan öntest-sontest toplam 35 çoktan seçmeli sorudan oluşmaktadır. Test bir soru kökü ve muhtemel cevaplardan oluşmaktadır. Testte, katılımcı verilen açıklama ve soru köküne göre en uygun ya da doğru cevabı seçmektedir. Öntestsontest madde kökü, seçenekler (cevap şıkları), anahtarlanmış cevap (doğru cevap) ve çeldirici olmak üzere madde formunu oluşturan dört öğeden oluşmaktadır. Testte sırasıyla "Akarsu ekosistemleri ve akarsulardan faydalanma", "Hidroelektrik santralleri nedir? Neden yapılır?", "Hidroelektrik

3 Görüşüne başvurulan uzmanlar Ankara Üniversitesi Eğitim Bilimleri Fakültesi öğretim elemanlarından Prof. Dr. Gürcan GÜRGEN, Yrd. Doç. Dr. Onur ÇALIŞKAN ve Arş. Gör. Nevzat Samet BAYKAL'dır. 
santrallerinin insan üzerinde olumlu etkileri (enerji, su, yenilenebilir kaynaklar)", "Hidroelektrik santrallerinin insan üzerinde olumsuz etkileri (insan, kültür, kirli su)", "Hidroelektrik santrallerinin doğa üzerinde olumsuz etkileri (kirli su, ölü ekosistem)", "Hidroelektrik santrallerinin fayda maliyet analizi, kalıcı zararları. Tribünler durduktan sonra ne oldu?” başlıkları altında sorular hazırlanmıştır.

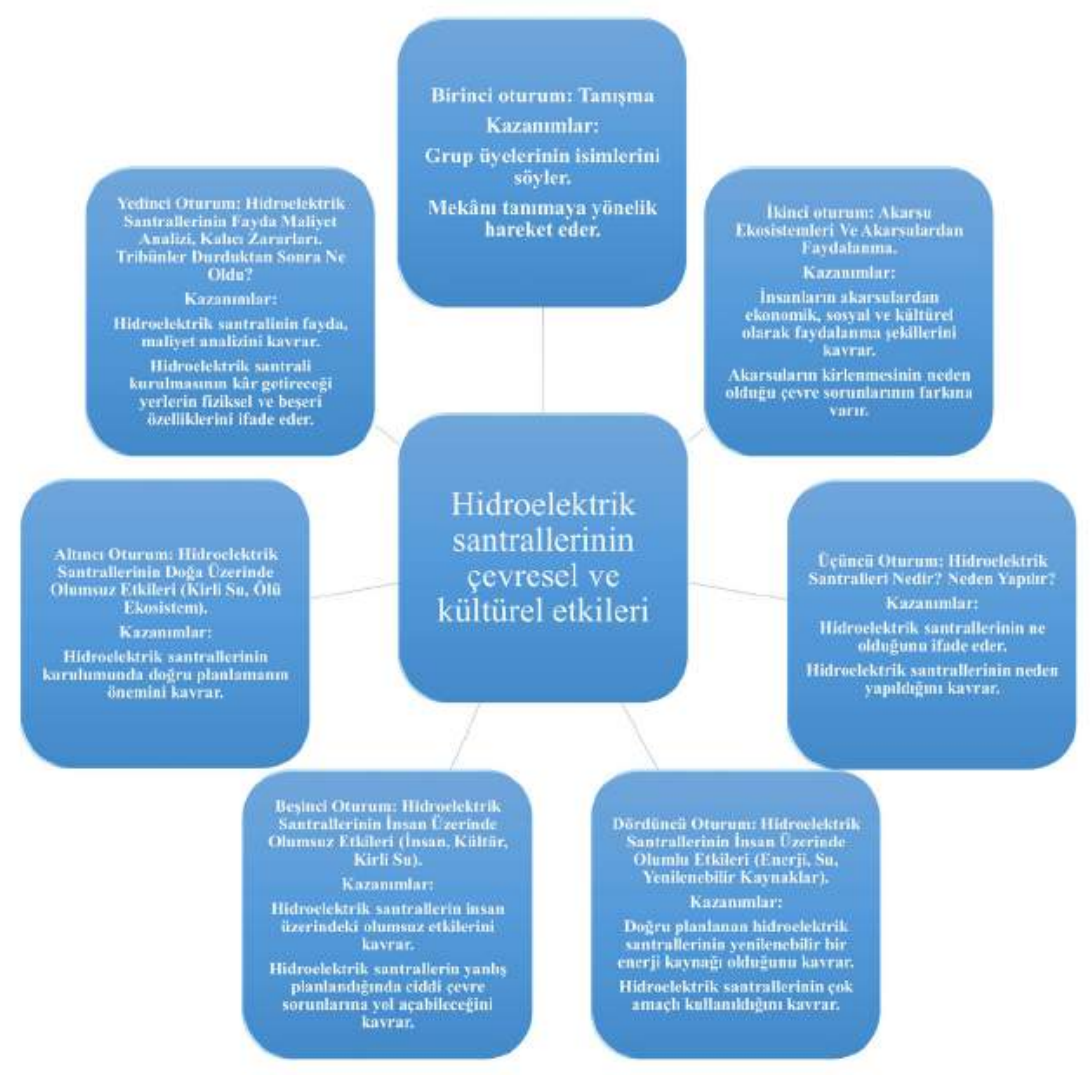

Şekil 2. Drama atölyelerinin özellikleri

\section{Verilerin Toplanması}

HES'lerin çevresel ve kültürel etkilerinin bütüncül bir bakış açısıyla kazandırılması kapsamında araştırma grubuyla 16.04.2016 - 01.05.2016 tarihleri arasında 21 saatten oluşan toplam yedi oturum şeklinde yaratıcı drama atölyeleri gerçekleştirilmiştir. Oturumlar, Ankara İli, Çankaya İlçesi, Ankara Üniversitesi Eğitim Bilimleri Fakültesi, 12 No' lu derslikte (coğrafya dersliğinde) ve Ankara Üniversitesi Sağlık Kültür ve Spor Dairesi Başkanlığı Kültür Sanat Merkezi yaratıcı drama atölyesinde gerçekleştirilmiştir. Gerçekleştirilen atölyelerin başlıklarını ve kazanımlarını Şekil 2'de bulunmaktadır. Birinci oturumda tanışma, grup iletişim ve etkileşiminin sağlanmıştır. İkinci oturum Akarsu ekosistemleri ve akarsulardan faydalanma kapsamında gerçekleştirilmiştir. Üçüncü oturumda hidroelektrik santrallerinin ne olduğu ve neden inşa edildikleri ele alınmıştır. Dördüncü oturumun konusu HES'lerin insan üzerindeki olumlu etkileridir. Beşinci oturumda ise HES'lerin insan üzerindeki olumsuz etkileri değerlendirilmiştir. Altıncı oturumda HES'lerin doğa üzerindeki olumsuz etkileri (kirli su, ölü ekosistem), yedinci ve son oturumda ise HES'lerin fayda maliyet analizi ve olası kalıcı zararları ele alınmıştır. Çalışma grubuna yaratıcı drama atölyeleri öncesinde öntest uygulanmış ve 21 saatlik çalışma sonrasında sontest uygulanmıştır. 


\section{Verilerin Analizi}

Verilerin analizinde frekans analizi ve wilcoxon testi kullanılmıştır. Frekans analizi bir seri içinde bir değer ya da özelliğin tekrarlanma sıklığının değerlendirildiği betimsel analiz yöntemidir. Değerin seri içinde aldığı her bir tercih için bir sıklık puanı almasına dayalıdır. Bir sayı ile ifade edilebileceği gibi yüzde olarak da ifade edilebilmektedir. Katılımcıların öntest ve sonteste verdikleri yanıtların frekans analizi gerçekleştirilmiştir.

"Wilcoxon" testi eşleştirilmiş gruplara ilişkin farklılıkların boyutlarını da dikkate alarak iki değişkene ait dağılımın aynı olup olmadığını test etmek amacıyla geliştirilmiş bir analiz yöntemidir. "Paired” eşleştirilmiş “t” testinin parametrik olmayan karşılığıdır, "n” birimlik örnekten elde edilen iki gözlem grubu farkının ortancası sıfır olan toplumdan çekilmiş rasgele örnek olup olmadığını test eder. Bağımlı değişkenlere ilişkin veriler;

- Sayısal karakterler ile ifade edilmelidir.

- Sürekli veri olmalıdır.

- Aralık veya oran ölçeğindedir (Ott ve Longnecker, 2015, pp. 352-353).

Öntestte katılımcıların işaretledikleri doğru sayısı ve sontestte işaretledikleri doğru sayısı karşılaştırılarak analiz edilmiştir. Her bir katılımcının aldığı toplam puan hesaplanmıştır. Pozitif sıralamalar, negatif sıralamalar, ortalama, standart sapma, maksimum ve minimum değerler üzerinden sonuçlara ulaşı1mıştır.

\section{Bulgular}

Hidroelektrik santrallerinin çevresel etkilerinin eğitiminde yaratıcı dramanın bir yöntem olarak kullanılmasın ve böylece çevre eğitiminde yaratıcı dramanın etkililiğinin belirlenmesi amacıyla gerçekleştirilen çalışmada katılımcıların öntest ve sontest sonuçları Tablo 1'de verilmiştir. Toplam 35 sorunun bulunduğu test 16 katılımcıya da uygulanmıştır. 16 katılımcının öntest ortalaması 18,38 , sontest ortalaması ise 24,44 'tür. Katılımcılardan öntestte elde edilen minimum doğru sayıs 8 , maksimum doğru sayısı ise 24'tür. Sontestte en az doğru yanıta sahip olan katılımcının aldığı puan 20, en fazla doğru yapan ise 30'dur (Tablo 2). Öntest sonuçlarından hesaplanan standart sapma 4,759, sontest standart sapması ise 2,851'dir. Bu sonuçlara göre katılımcıları öntest ve sontest arasında ortalama 6,06 (\%17) puan daha başarılı olmuşlardır.

Tablo 1. Öntest sontest sonuçları betimsel istatistikleri

\begin{tabular}{lccccc}
\hline Test Türü & N & Ortalama & Standart sapma & $\begin{array}{c}\text { Minimum doğru } \\
\text { sayısı }\end{array}$ & $\begin{array}{c}\text { Maksimum } \\
\text { doğru sayısı }\end{array}$ \\
\hline Öntest & 16 & 18,38 & 4,759 & 8 & 24 \\
Sontest & 16 & 24,44 & 2,851 & 20 & 30 \\
\hline
\end{tabular}

Sontest standart sapmasının daha düşük olması sontestte elde edilen sonuçların ortalamaya yakınlaştığını göstermektedir. Standart sapmanın daha düşük değerleri sontestte başarı değerlerinin birbirine daha yakın olduğunu, katılımcılar arası başarı farkların azaldığını göstermektedir. Öntest sontest sonuçlarına göre HES'lerin çevresel etkilerinin konu edildiği yaratıcı drama projesi başarılı olmuştur. 16 katılımcının tamamında sontest puanları daha yüksektir (Tablo 1). Başarı artış yüzdeleri 
incelendiğinde en düşük değerin \%3, en yüksek değerin ise \%57 olduğu gözlenmektedir (Tablo 2).

Yaratıcı drama projesine dâhil olan katılımcıların büyük bir bölümünün (13 kişi) başarı oranlarının \%5'den yüksek olduğu gözlenmektedir. Öntest ve sontest puanlarının karşılaştırılması bütün katılımcıların proje sonucunda anlamlı bir ilerleme kaydettiğini göstermektedir. Yapılan testin asimtotik anlamlılık düzeyi 0,000 olarak hesaplanmıştır. Bu değer yapılan yaratıcı drama çalışması sonunda katılımcıların aldığı başarı puanındaki artışın istatistiki olarak anlamlı olduğunu ortaya koymaktadir. (Tablo3).

Katılımcıların öntest ve sontest sonuçlarının atölyelere göre değerlendirilmesi Tablo 4'te verilmiştir. Toplam altı atölyenin tamamında katılımcıların aldığı sontest başarı puanının öntest başarı puanından daha yüksek olduğu hesaplanmıştır. Sorulara verilen doğru yanıtların ortalaması öntest için 8,4 iken sontestte bu sayı 11,2'ye yükselmiştir. Bütün sorular dikkate alındığında katılımcıların \% 17,5 daha başarılı olduğu anlaşılmaktadır. Verilen toplam doğru yanıt sayısı önteste 294, sontestte ise 391 olarak hesaplanmıştır (Tablo 2).

Tablo 2. Katılımcıların öntest ve sontestten aldıkları puanlar

\begin{tabular}{lcccc}
\hline Katılımcılar & Öntest Sonucu & Sontest Sonucu & Fark & Başarı Yüzdesi \\
\hline Katılımc1 1 & 20 & 22 & 2 & 5,7 \\
Katılımc1 2 & 20 & 21 & 1 & 2,9 \\
Katılımc1 3 & 11 & 23 & 12 & 34,3 \\
Katılımc1 4 & 20 & 22 & 2 & 5,7 \\
Katılımc1 5 & 19 & 20 & 1 & 2,9 \\
Katılımc1 6 & 8 & 28 & 20 & 57,1 \\
Katılımc1 7 & 24 & 25 & 1 & 2,9 \\
Katılımc1 8 & 23 & 28 & 5 & 14,3 \\
Katılımc1 9 & 18 & 23 & 5 & 14,3 \\
Katılımc1 10 & 14 & 24 & 10 & 28,6 \\
Katılımc1 11 & 12 & 28 & 16 & 45,7 \\
Katılımc1 12 & 19 & 24 & 5 & 14,3 \\
Katılımc1 13 & 23 & 26 & 3 & 8,6 \\
Katılımc1 14 & 18 & 24 & 6 & 17,1 \\
Katılımc1 15 & 22 & 23 & 1 & 2,9 \\
Katılımc1 16 & 23 & 30 & 7 & 20,0 \\
\hline
\end{tabular}

Tablo 3. Wilcoxon testi sonuçları

\begin{tabular}{llccc}
\hline Hesaplama & Sıralama & N & Ortalama & Siralama Toplamı \\
\hline Sontest - Öntest & Negatif sıralama & 0 & 0 & 0 \\
& Pozitif sıralama & 16 & 8,50 & 136,00 \\
& Değişim olmayanlar & 0 & &
\end{tabular}

$Z=-3,525$

Asimtotik anlaml1l1k $=0,000$ 
İkinci oturum konusunu oluşturan "Akarsu ekosistemleri ve akarsulardan faydalanma" başlığı altında katılımcılara toplam altı soru verilmiştir. Öntestte 47 olan doğru yanıt sayısı sontestte 64'e yükselmiştir. Bu sonuçlara göre yapılan drama atölyesinin katılımcıların başarısını \%17,7 oranında arttırdığı hesaplanmıştır. Yaratıcı drama yöntemiyle yapılan çalışmalar katılımcıların akarsu ekosistemleri ve akarsulardan faydalanma konularında geliştiklerini işaret etmektedir. Katılımcıların insanların akarsulardan ekonomik, sosyal ve kültürel olarak faydalanma şekillerini kavradığı, akarsuların kirlenmesine neden olan çevre sorunlarının farkına vardığı gözlenmektedir (Tablo 4).

Tablo 4. Atölyelere göre öntest-sontest sorularının Wilcoxon testi sonuçları

\begin{tabular}{lcccccc}
\hline Sorular & Öntest doğru yanıt & $\begin{array}{c}\text { Sontest doğru } \\
\text { yanıt }\end{array}$ & $\begin{array}{c}\text { Öntest } \\
\text { ortalama }\end{array}$ & $\begin{array}{c}\text { Sontest } \\
\text { ortalama }\end{array}$ & Fark & Başarı yüzdesi \\
\hline 2. Oturum & 47 & 64 & 7,8 & 10,7 & 17 & 17,7 \\
3. Oturum & 54 & 59 & 9,0 & 9,8 & 5 & 5,2 \\
4. Oturum & 57 & 84 & 9,5 & 14,0 & 27 & 28,1 \\
5. Oturum & 64 & 81 & 10,7 & 13,5 & 17 & 17,7 \\
6. Oturum & 42 & 55 & 7,0 & 9,2 & 13 & 13,5 \\
7. Oturum & 30 & 48 & 6,0 & 9,6 & 18 & 22,5 \\
Toplam & 294 & 391 & 8,4 & 11,2 & 97 & 17,5 \\
\hline
\end{tabular}

Üçüncü oturum konusunu oluşturan "Hidroelektrik santralleri nedir, neden yapılır?” başlığı katılımcıların en az gelişme gösterdiği atölye çalışmasıdır. Bu atölyeye ait toplam altı soru katılımcılara yöneltilmiştir. Önteste verilen doğru yanıt sayısı 54, sontestte verilen doğru yanıt sayıs1 59'dur. Öntest ortalamas1 9, sontest ortalamas1 9,8' dir. Diğer atölyelere nazara daha düşük bir başarı gelişimi gözlenmiş olmakla birlikte Wilcoxon testi sonuçlarına göre \%5,2'lik bir başarı artışı gözlenmiştir. Bu sonuçlara göre gerçekleştirilen yaratıcı drama çalışmasında hidroelektrik santrallerinin ne olduğu ve neden yapıldığ 0,000) bir artış gözlenmiştir (Tablo 4).

Dördüncü oturumda ele alınan "Hidroelektrik santrallerinin insan üzerinde olumlu etkileri (enerji, su, yenilenebilir kaynaklar)" konusu katılımcıların en fazla gelişim gösterdikleri alandır. Bu konuya özgü toplam altı soru bulunmaktadır. Bu atölye öncesinde yapılan testteki 57 olan doğru yanıt sayısı, sonrasında 84'e yükselmiştir. Öntestte 9,5 olan doğru yanıt ortalaması, sontestte 14'e yükselmiştir. $\mathrm{Bu}$ sonuçlar katılımcıların başarısının \%28'in üzerinde bir artış gösterdiğinin işaret etmektedir. Gerçekleştirilen yaratıcı drama çalışması sonucunda doğru planlanan hidroelektrik santrallerinin yenilenebilir bir enerji kaynağı olduğunu kavramak noktasında anlamlı bir gelişme yaratılmıştır. Bunun yanı sıra hidroelektrik santrallerinin çok amaçlı kullanımı konusunda da katılımcıların önemli bir gelişme kaydettiği anlaşılmaktadır (Tablo 4).

Beşinci oturumdaki kavram ve kazanımların ölçülmesi için altı soru kullanılmıştır. "Hidroelektrik santrallerinin insan üzerinde olumsuz etkileri (insan, kültür, kirli su)" başlığını taşıyan bu atölye çalışmasının öncesinde katılımcıların doğru yanıtlarının toplamı 64'ken, sontestte doğru yanıt sayısı 81 'e yükselmiştir. Yaratıcı drama yönteminin başarı oranını \%17,7'ye kadar yükseltmiştir. Öntest ortalaması 10,7, sontest ortalaması 13,5 olarak hesaplanmıştır. Bu sonuçlar doğrultusunda katılımcıların hidroelektrik santrallerinin insanlar üzerinde olumsuz etkileri konusunda anlamlı bir gelişme gösterdiği anlaşılmaktadır (Tablo 4). 
Altıncı oturumda ele alınan konu başlı̆g 1 "Hidroelektrik santrallerinin doğa üzerinde olumsuz etkileri (kirli su, ölü ekosistem)" olarak yapılandırılmıştır. Bu atölyede gerçekleştirilen çalışmaların değerlendirilmesi için soru sayısı altıdır. Öntestte verilen doğru yanıt sayısı 42, sontestteki doğru yanıt sayısı ise 55'tir. Katılımcıların doğru yanıt sayılarının 13 arttığı, başarı yüzdelerinin ise \%13,5 oranında yükseldiği hesaplanmıştır. Öntestteki ortalama 7'yken, sontestte ortalama 9,2'ye yükselmiştir. $\mathrm{Bu}$ sonuçlar doğrultusunda gerçekleştirilen çalışmanın katılımcıların hidroelektrik santrallerinin doğa üzerindeki olumsuz etkilerinin kavranması konusunda istatistiki olarak anlamlı bir gelişme gösterdikleri ortaya çıkmaktadır (Tablo 4).

Yedinci oturum kapsamında yer alan soru sayısı beştir. Bu atölyenin konusunu "Hidroelektrik santrallerinin fayda maliyet analizi, kalıcı zararları nelerdir? Tribünler durduktan sonra ne oldu?" olarak özetlenmiştir. Katılımcıların testlerde elde ettikleri puanlar bakımından en yüksek ikinci gelişmenin ortaya çıktığı atölye olması bakımından da dikkat çekicidir. Öntest doğru yanıt sayısı 30 'ken, sontestte bu rakam 48'e yükselmiştir. Dolayısıyla yapılan istatistiki analizler sonucunda katılımcıların başarısının \%22,5 arttığı hesaplanmıştır. Öntest ortalaması 6'dan, sontestte 9,6'ya yükseltilmiştir. Hidroelektrik santrallerinin fayda-maliyet analizini kavratmada ve hidroelektrik santrali kurulması planlanan alanların seçiminde dikkat edilmesi gerekenler konusunda katılımcılarda anlamlı bir gelişme yaşandığı açıktır. Yaratıcı drama çalışması hidroelektrik santrallerinin fiziki ve beşeri etkilerinin kavratılmasında önemli bir aşama kaydedilmesini sağlamıştır (Tablo 4).

\section{Tartışma, Sonuç ve Öneriler}

Bu çalışmada çevre eğitiminde ve özellikle hidroelektrik santrallerinin çevresel etkilerinin eğitiminde yaratıcı dramanın bir yöntem olarak kullanılması değerlendirilmiştir. Yaratıcı drama çalışmasına katılan öğretmen adaylarının öntest başarı puanı ve sontest başarı puanı karşılaştırıldığında önemli oranlarda bir gelişme yaşandığı gözlenmektedir. Wilcoxon testi sonuçları bütün katılımcıların sontestte daha yüksek puan aldığını göstermektedir. Alamlılık değerinin sıfıra çok yakın olması başarı puanlarındaki artışın istatiksel olarak geçerli olduğunu ortaya koymaktadır. Yaratıcı drama yöntemi katılımcıların başarısını \%3 ile \%57 arasında yükseltmiştir. Bunun yanı sıra sontestte elde edilen standart sapma puanının öntest puanına göre düşük olduğu hesaplanmıştır. Bu durum öğrencilerin başarı puanlarının birbirine yaklaştığını, düşük ve yüksek puanlar arasındaki farkın azaldığını göstermektedir. Hidroelektrik santrallerinin çevresel etkilerinin farklı boyutlarının ele alındığı kazanım alanlarının tamamında katılımcıların ciddi oranlarda gelişme gösterdiği bir diğer ulaşılan sonuçtur. Yaratıcı drama grubun tamamına ve konunun bütününe yayılmış bir öğretmeöğrenme yöntemi olarak başarıyı yükselten bir yöntemdir.

Elde edilen bu bulgular farklı ülkelerde gerçekleştirilen çevre eğitimi uygulamalarıyla benzer sonuçlar ortaya koymuştur. Sürdürülebilirlik kavramını eğitsel drama yöntemiyle işlediği çalışmasında McNaugton (2004) katılımcı ve aktif öğrenmenin gerçekleştiğini ortaya koymuştur. Çalışmaya katılan öğrencilerin çevre sorunları yaşayan insanlara empati ve sempati kurmasını da sağladığ1 sonucuna ulaşılmıştır. Bu çalışmada elde edilen bulgulara paralel olarak Levey (2005) çevre konularının öğretiminde yaratıcı dramanın öğrenci başarısını arttırdığı savunmaktadır. Ayrıca dönüştürülebilir becerileri geliştirmesi bakımından da yaratıcı dramanın etkin bir yöntem olduğu sonucuna ulaşmıştır. Curtis vd. (2013) dramanın, yaratıcı ve çok katmanlı yapısıyla öğrencileri heyecanlandıran, dikkatlerini koruyan ve katılımlarını kolaylaştıran bir yöntem olarak bilimsel 
araştırmaları sentezleme ve sunma aracı olduğunu ortaya koymuşlardır. Bu çalışmada kullanıldığı gibi çevre eğitimi konularının anlaşılması açısından önemini vurgulamışlardır.

Hidroelektrik santrallerinin doğa ve insanlara etkileri farklı boyutlara sahip, bir hayli karmaşık bir çevre eğitimi alanıdır. Akarsu ekosistemleri ve akarsulardan faydalanma, HES'lerin doğal ya da beşeri sistemler üzerinde olumlu ve/veya olumsuz etkileri ve HES planlama konularında yaratıcı drama yöntemi bütünlüklü bir gelişme sağlamıştır. HES'ler gibi çevresel etkilerinin karmaşık olduğu konularda başarılı sonuçlar alınması, çevre eğitiminde yaratıcı dramanın tercih edilmesi elzem bir yöntem olduğunu ortaya koymaktadır. Katılımcılar yaratıcı drama yöntemiyle daha etkili ve kalıcı bir öğrenme süreci içine girmişlerdir.

Atölyeler sonunda öğrencilerin görüşlerini kaydedilmiştir. Katılımcılar, yaratıcı drama atölyelerinin çevre eğitimi konularındaki bilgi, birikim ve deneyimleri arttırdığını belirtmiştir. Bununla birlikte dönüştürülebilir becerilerinde de kayda değer bir gelişme olduğunu fark etmişlerdir. Takım çalışması, iletişim, kendini sözlü ya da yazılı ifade etme, liderlik, analitik düşünme gibi dönüştürülebilir becerilerini bu süreç sonucunda geliştirdikleri beyan etmişlerdir.

İnsanların çevreye verdiği zarar, Dünya’yı yaşanamaz bir gezegen haline getirmektedir. İnsan eliyle ortaya çıkan çevresel değişimlerden en fazla etkilenen canlı türü yine insandır. Çevre eğitimi sürdürülebilir kalkınma açısından önemli olduğu kadar, insan ırkının yeryüzündeki devamı açısından da önemlidir. Etkili bir öğrenme yöntemi olan yaratıcı drama hayati bir öneme sahip çevre eğitimi konularının işlenmesinde de anlamlı sonuçlar vermektedir. Yaratıcı drama çevre eğitiminin bütün amaçlarına uygun süreçlerin yürütülmesinde ve materyallerin ortaya çıkarılmasında kalıcı öğrenmeyi tetikleyecektir. Çevre eğitiminde yaratıcı dramanın kullanılması kısa zamanda etkili sonuçlar verirken uzun vadede anlamlı öğrenmeyi kazandırmaktadır. Çevre eğitimi konularında yaratıcı dramanın kullanılması sadece bireylerin değişmesini değil toplulukların da değişmesine ön ayak olacaktır. Toplumların değişmesi gezegenin daha sağlıklı, daha temiz ve daha sürdürülebilir bir yer haline gelmesini sağlayacaktır. 


\section{Kaynakça}

Adıgüzel, Ö. (2014). Eğitimde yaratıcı drama. Ankara: Pegem Akademi.

Alpar, R. (1997). Uygulamalı çok değişkenli istatistiksel yöntemlere giriş-I. Ankara: Bağırgan Yayımevi.

Ayas, C. (2010). Yine yeni yeniden yenilenebilir enerji. İstanbul: WWF-Türkiye (Doğal Hayatı Koruma Vakfi).

BP. (2009). Statistical review of world energy 2007. London: British Petroleum.

Büyüköztürk, Ş. (2001). Deneysel desenler: Öntest sontest kontrol gruplu desen ve veri analizi. Pegem Yayınları, Ankara.

Curtis, D. J., Howden, M., Curtis, F., McColm, I., Scrine, J., Blomfield, T., . . Ryan, T. (2013). Drama and Environment: Joining forces to engage children and young people in environmental education. Australian Journal of environmental education, 29 (2), 182.

Demirel, Ö. (2014). Öğretim ilke ve yöntemleri ögretme sanatı. Ankara: Pegem Akademi Yayıncılık.

Di Pietro, R. J. (1987). Strategic interaction: Learning languages through scenarios. Cambridge: Cambridge Univ Press.

Donato, R., \& McCormick, D. (1994). A sociocultural perspective on language learning strategies: The role of mediation. The Modern Language Journal, 78(4), 453-464.

Karasar, N. (2012). Bilimsel araştırma yöntemi: kavramlar, ilkeler, teknikler. Ankara: Nobel Yayın Dağıtım.

Levey, S. (2005). Drama in environmental education. Green teacher, (77), 15-25.

Lukinsky, J. (1990). Reflective withdrawal through journal writing. In J. Mezirow (Ed.), Fostering critical reflection in adulthood: A guide to transformative and emancipatory learning. San Francisco: Jossey-Bass higher education series.

McKenzie, P. (1983). WG Armstrong: The Life and Times of Sir William George Armstrong, Baron Armstrong of Cragside. Northumberland: Longhirst.

McNaughton, M. J. (2004). Educational drama in the teaching of education for sustainability. Environmental Education Research, 10(2), 139-155.

Mezirow, J. (1990). Fostering critical reflection in adulthood. San Francisco: Jossey-Bass Higher Education Series.

Miccoli, L. (2003). English through drama for oral skills development. English Language Teaching Journal, 57(2), 122-129.

Ott, R. L., \& Longnecker, M. T. (2015). An introduction to statistical methods and data analysis. Boston: Cengage Learning.

Parsons, C. A. (2012). The steam turbine: The rede lecture 1911. New York: Cambridge University Press.

Schön, D. A. (1991). The reflective turn: Case studies in and on educational practice. New York: Teachers College Press.

Üstündağ, T. (2000). Yaratıcı drama ögretmeninin günlüğ̈̈. Ankara: Pegem Akademi Yayıncılık

Via, R. A. (1976). English in three acts. Hong Kong: The University Press of Hawaii.

Wagner, B. J. (1976). Dorothy Heathcote: Drama as a learning medium. Washington, DC: National Educational Association.

Windsor, J., Benigno, J. P., Wing, C. A., Carroll, P. J., Koga, S. F., Nelson, C. A., Zeanah, C. H. (2011). Effect of foster care on young children's language learning. Child Development, 82(4), 1040-1046.

Yılmaz, C., Ali, U., Zeybek, H. İ., \& Mutlu, K. (2012). Nehir tipi hidroelektrik santrallerinin coğrafi ortam üzerine etkilerine bir örnek: Ayancık HES. NWSA: Nature Sciences, 7(3), 50-67.

Yurtseven, I. (2011). Ecohydrological effects of run-of-river type hydroelectric power plants on the watersheds. Journal of the Faculty of Forestry Istanbul University, 61(1), 55-62. 


\section{Ek 1: Örnek Ders Planı (3. Oturum)}

Ders: Yaratıc1 Drama

Konu: Hidroelektrik Santralleri Nedir? Neden Yapılır?

Grup: Ankara Üniversitesi Eğitim Bilimleri Fakültesi / Sosyal Bilgiler Öğretmenliği Programı Öğrencileri (16 kişi; 10 Kadın / 6 Erkek) / "Yaratıcı Drama" geçmişleri yok.

Süre: 180 Dakika

Kullanılan Yöntem/Teknikler: Yaratıcı Drama/Doğaçlama, Rol Oynama, Donuk İmge, Liderin Role Girmesi, Eş Zamanlı Doğaçlama, İstasyon Tekniği.

Araç-Gereçler: Elektrik üretme türlerinden bazılarının (Pil, Akü-Akım toplar- Batarya ya da Biriktireç, Güneş Enerjisi Santralleri / Güneş Pili ( Hücresi), Hidrojen Yakıt Pili (Hücresi), Termik Santral, Rüzgâr Türbini, Hidroelektrik Enerji Santral, Jeotermik Santral, Gel-git Enerjisi...) yazılı olduğu bilgi kartları ve resimleri, A-B kişilerine ait eş zamanlı doğaçlama konularının yazılı olduğu kartlar, 1 adet büyük fon kartonu, patafix yapıştırıcı, A4 kâğıt, kalem, silgi.

Mekân: Ankara Üniversitesi SKS Binası Yaratıcı Drama Atölyesi ve Ankara Üniversitesi Eğitim Bilimleri Fakültesi 12 No' lu Derslik.

\section{Kazanımlar:}

- Hidroelektrik santrallerinin ne olduğunu ifade eder.

- Hidroelektrik santrallerinin neden yapıldığını kavrar.

\section{Süreç}

\section{A-Hazırlık / Isınma:}

\section{Etkinlik:}

Eğitmen katılımcılara sol ellerini açık şekilde sırtlarına koymalarını, sağ el işaret parmaklarını da önde tutmalarını söyler. Amaçlarının sırtlarında yer alan ellere dokunup karşısındaki kişiye elektrik akımı vermek ve bunu yaparken de kendilerini korumaya çalışmak olması gerektiğini söyler. Elektrik akımını alan kişi oyundan çıkar.

\section{Etkinlik:}

Katılımcılarla birlikte çember olunur. Eğitmen "Mekânda serbest halde yürüyelim... Elektrikle çalışan aletleri düşünelim... Bu düşündüklerimiz arasından bir tanesini olmak istesek hangisi olurduk?... Kısa bir yapılandırma yapalım... Kendimizi hazır hissettiğimizde lütfen o aletin formunu alarak donalım. Yalnız hangi aleti olduğumuzu kimseyle paylaşmayalım..." der. Katılımcılar bir süre sonra donar. Sonra eğitmen "Bu kadar eşyaya ihtiyacım yok. Evimin içi eşyayla doldu. Bunlardan bir kısmını atmalıyım" der. Katılımcılardan birini seçerek "İşte buna hiç ihtiyacım yok, bunu hemen atacağım” der. Katılımcı da onu neden atmaması gerektiğini açıklar. Süreç bu şekilde devam eder ve sonlandirilır.

\section{Etkinlik:}

Eğitmen elektrik üretme türlerinden (Pil, Akü-Akım toplar- Batarya ya da Biriktireç, Güneş Enerjisi Santralleri / Güneş Pili ( Hücresi), Hidrojen Yakıt Pili (Hücresi), Termik Santral, Rüzgâr 
Türbini, Hidroelektrik Enerji Santral, Jeotermik Santral, Gel-git Enerjisi...vs) bazılarına ait bir pano hazırlar ve bunu mekânın duvarına asar. Ayrıca hazırlamış olduğu bilgi kartlarını mekânda yere bırakır. Katılımcılara bu bilgi kartlarını panodaki resimlere bakarak eşlemelerini söyler.

"Not: Bilgi kartlarındaki yer alan ifadenin hangi elektrik üretme türüne ait olduğu belirtilmemektedir."

\section{B-Canlandirma:}

\section{Etkinlik:}

Eğitmen katılımcılara çember olmalarını ve A-B şeklinde sırayla saymalarını söyler. Elektrik üretme türlerinden (Pil, Akü-Akım toplar- Batarya ya da Biriktireç, Güneş Enerjisi Santralleri / Güneş Pili ( Hücresi), Hidrojen Yakıt Pili (Hücresi), Termik Santral, Rüzgâr Türbini, Hidroelektrik Enerji Santral, Jeotermik Santral, Gel-git Enerjisi...vs) hakkında bir fuar olduğunu ve kendilerinin de bu fuara katıldıklarını ekler. Ardından A'lara bir önceki etkinlikte kullanılan bilgi kartlarını almalarını ve fuarı gezmeye gelen B'lere bunlar hakkında bilgi vermelerini söyler (Ek 1). Bir süre sonra A'lar ve B'ler rol değiştirir, süreç yeniden tekrarlanır.

\section{Etkinlik:}

Katılımcılar 1'den 4'e kadar sayarak, dört grup oluşturur. Eğitmen her grubun bir önceki etkinlikten yola çıkarak elektrik üretme türlerinden birini canlandırmalarını söyler. Gruplar canlandırmalarını yaptıktan sonra katılımcılar da elektrik üreten birimlerden hangisi olduğunu tahmin eder.

\section{Ara Değerlendirme:}

Her bir canlandırma sonrası canlandırmalardan yola çıkarak katılımcılara neler anlatıldı̆̆ ve neler anladıklarıyla ilgili sorular sorulur. Ayrıca elektrik üreten bu birimlerin olumlu, olumsuz yönleri üzerine bildikleri kadarlyla konuşulur.

\section{Etkinlik:}

Çember olunur. Ardından mekânda serbest halde yürünür. Eğitmen "Yaşadığımız ülkenin çok fazla akarsuya ve yemyeşil bir doğaya sahip olduğunu düşünelim... Yürümeye devam edelim... Gayri safi milli hasılanın düşük olduğu bir ülkede yaşıyorsunuz... Çok fazla geliriniz yok... Gelirlerinizi arttırmanın yollarını arıyorsunuz. Hükümet ve muhalefetin bu yöndeki bakış açıları ise birbirinden çok farklı" der. Ardından katılımcılara en yakınındaki kişilerle ikili gruplar oluşturmalarını ve kendi aralarında A-B kişileri olarak ayrılmalarını söyler.

A kissisi; İktidar, sanayinin geliştirilmesi gerektiğini bu yüzden de ülkedeki bütün büyük akarsuların üzerine hidroelektrik santralleri kurulması gerektiğini savunur.

B kisisi; Muhalefet, akarsu ekosistemlerini yok etmek yerine turizme yatırım yapılmas1, akarsuların da bu şekilde değerlendirilmesi gerektiğini savunur.

Bu konulara göre eş zamanlı doğaçlamalar yapılır.

\section{Etkinlik:}

Katılımcılar 1'den 4'e kadar sayarak dört grup oluşturur. Eğitmen 'Ülkenizde günde sekiz saati aşkın elektrik kesintileri yaşanıyor. Hükümet en önemli su kaynakları üzerine barajlar yapacak yasayı çıkartmak için gerekli çoğunluğu sağlayamıyor. Kararı referanduma götürmek istiyor. Siz de ülkenin önde gelen siyasi partilerinin propaganda sorumlularısınız. Aranızda yasayı destekleyenler ve 
yasaya karşı çıkanlar var. Sizler bu yasa değişikliğine neden "evet” diyorsunuz? Ya da neden "hayır" diyorsunuz? Bu durumla ilgili içinde bir propaganda metninin de olduğu canlandırma hazırlayalım" $\operatorname{der}(\operatorname{Ek} 2)$.

\section{Ara Değerlendirme:}

Her bir canlandırma sonrası canlandırmalardan yola çıkarak katılımcılara neler anlatıldığı ve neler anladıklarıyla ilgili sorular sorulur. HES ler hakkında kısaca bilgi verilip katılımcılarla üzerine konuşulur.

\section{C-Değerlendirme:}

\section{Etkinlik:}

Katılımcılar 1'den 4'e kadar sayarak dört grup oluşturur ve yere oturur. İki grup negatif, iki grup pozitiftir. Eğitmen her bir gruba A4 kâğıt ve kalem dağıtır. Kâğıtların iki tanesinin üzerine daha önceden "Hidroelektrik santralleri nedir? Neden yapılmalı? İki tanesinin de üzerine Hidroelektrik santralleri nedir? Neden yapılmamalıdır?" soruları yazılır. Her grup kendi özelliklerine göre (negatif veya pozitif) bu soruların olumlu, olumsuz özelliklerine dair birer cümle yazar. İstasyon tekniği kullanarak fon kartonları gruplar arasında değiştirilir. Süreç bu şekilde devam eder ve sonlandırılır. Yazılanlar bütün grupla paylaşılır. Ölçüt:_Gruplardan "Hidroelektrik santralleri nedir? Neden yapılmalı? ya da Neden yapılmamalıdır?” sorularına en az dört madde yazmaları beklenir.

Eğitmen, herkese teşekkür ederek süreci sonlandırır.

\section{Üçüncü Oturum Ekleri}

\section{Ek 1:}

\section{3. ve 4. Etkinlikte Kullanılan Bilgi Kartları ve Resimler:}

Pil: Kimyasal enerjinin depolanabilmesi ve elektriksel bir forma dönüştürülebilmesi için kullanılan bir aygıttır. Bir veya daha fazla elektrokimyasal hücre, yakıt hücreleri veya akış hücreleri gibi, elektrokimyasal aygitlardan oluşur.

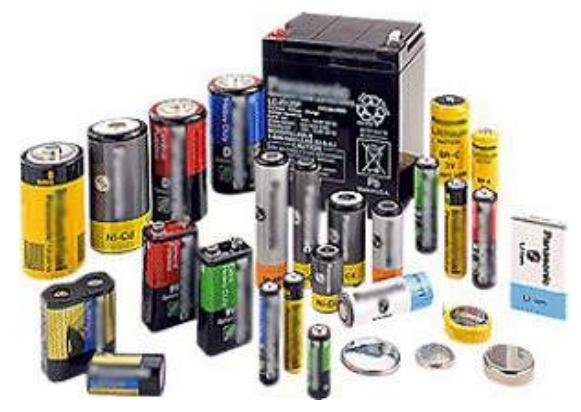

\section{Akü, Akım toplar, Batarya ya da Biriktireç}

Elektrik enerjisini kimyasal enerji olarak depo eden, istenildiğinde bunu elektrik enerjisi olarak veren cihaz, araçlarda bulunan elektrik enerjisi kaynağıdır. 


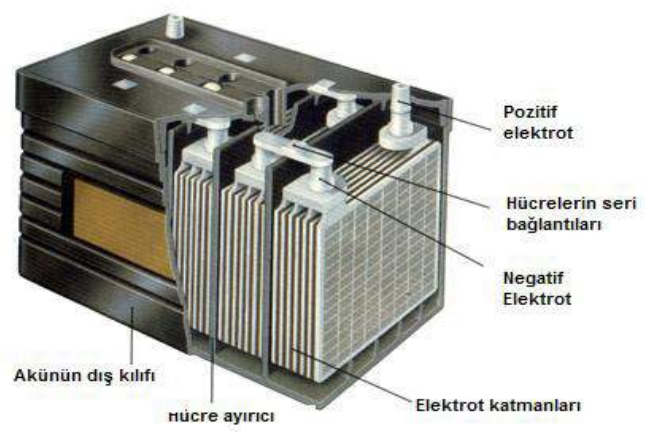

\section{Güneş Enerjisi Santralleri / Güneş Pili ( Hücresi)}

Güneş 1şı̆̆ından gelen enerji parçacıklarını elektrik enerjisine çeviren santrallerdir. Santrallerde, hesap makinelerindekine benzer fakat büyük ebatlarda kullanılır. Bunlar fotovoltaiktir. Üzerine gelen güneş 1şınlarını elektriğe çevirirler. Ana maddesi kristal silisyum ve galyum arsenittir.

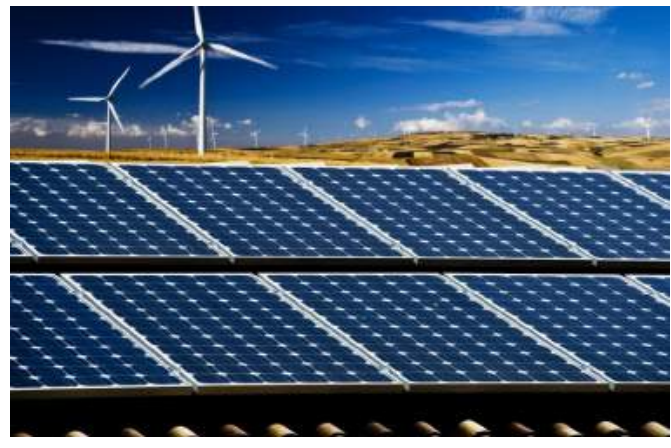

\section{Hidrojen Yakıt Pili (Hücresi)}

Yakıtın enerjisini elektrokimyasal reaksiyon sayesinde doğrudan elektrik enerjisine dönüştürür. Dışarıdan sağlanan yakıt (anot tarafı) ve oksitleyici (katot tarafı) ile elektrik üretir. Bunlar bir elektrolit/elektrot unitesinde reaksiyona girerler. Genellikle, reaksiyona girecek olanlar hücreye giriş yaparlarken, reaksiyon ürünleri hücreyi terk eder. Gerekli yakıt ve oksitleyici akışı sağlandığı sürece sonsuza dek çalışabilirler.

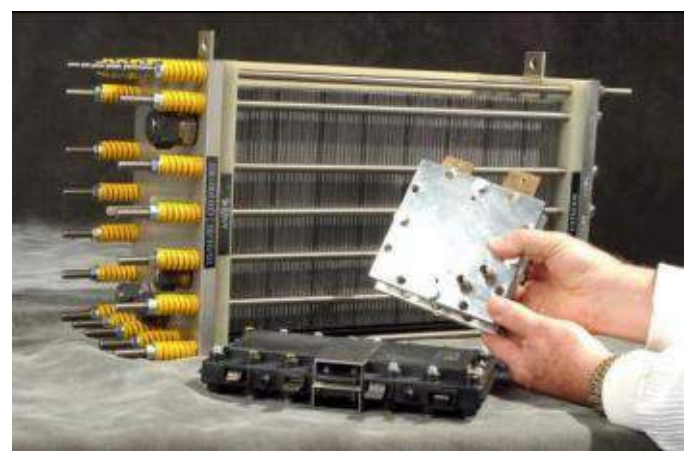

\section{Termik Santral}

Ana işletici makinesi buhar gücüyle çalışan güç santralidir. Isıtılan su buhara dönüştürülerek bir elektrik üretecini süren buhar türbinini döndürmekte kullanılır. Türbinden geçen buhar Rankine çevrimi denilen yöntemle bir yüzey yoğunlaştırıcıda yoğunlaştırılarak geri suya dönüştürülür. 
Tasarımları arasındaki en büyük farklılık kullandıkları yakıt tiplerine (Kömürlü, nükleer, jeotermal, güneş ve çöp, doğalgaz) göredir.

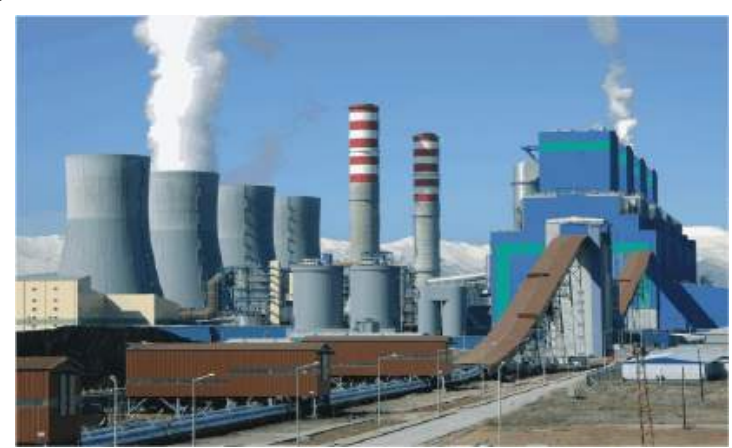

\section{Rüzgâr Türbini}

Rüzgârdaki kinetik enerjiyi önce mekanik enerjiye daha sonra da elektrik enerjisine dönüştüren sistemdir. Rüzgârın kinetik enerjisi rotorda mekanik enerjiye çevrilir. Rotor milinin devir hareketi hızlandırılarak gövdedeki jeneratöre aktarılır. Jeneratörden elde edilen elektrik enerjisi aküler vasıtasıyla depolanarak veya doğrudan alıcılara ulaştırılır.

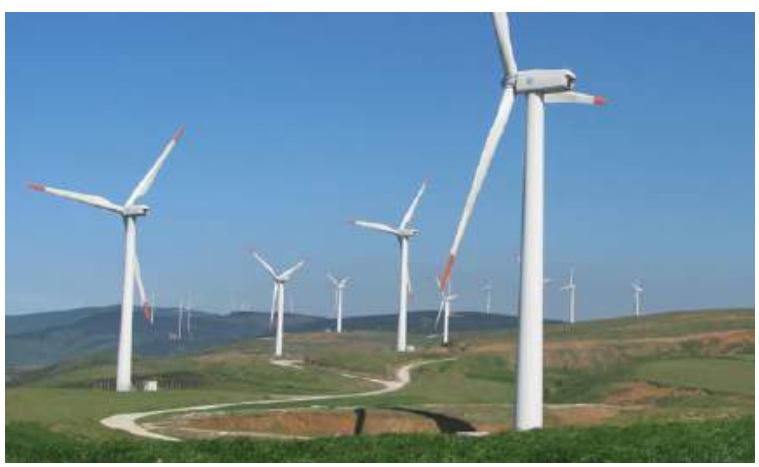

\section{Hidroelektrik Enerji Santral}

Akan suyun gücünü elektriğe dönüştürürler. Akan su içindeki enerji miktarını suyun akış veya düşüş hızı tayin eder. Büyük bir nehirde akan su büyük miktarda enerji taşımaktadır. Ya da su çok yüksek bir noktadan düşürüldüğünde de yine yüksek miktarda enerji elde edilir. Her iki yolla da kanal ya da borular içine alınan su, türbinlere doğru akar, elektrik üretimi için pervane gibi kolları olan türbinlerin dönmesini sağlar. Türbinler jeneratörlere bağlıdır ve mekanik enerjiyi elektrik enerjisine dönüştürürler.

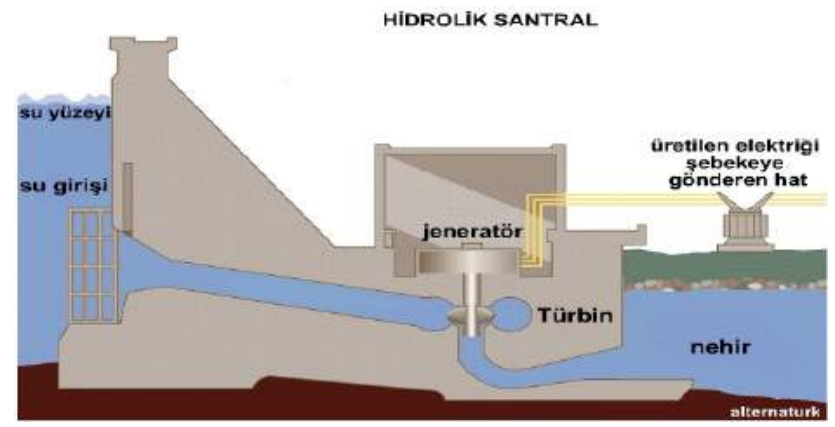




\section{Jeotermik Santral}

Yer 1sıs1 olup, yerkabuğunun çeşitli derinliklerinde birikmiş 1sının oluşturduğu, kimyasallar içeren sıcak su, buhar ve gazlardır. Yeni, yenilenebilir, sürdürülebilir, tükenmeyen, ucuz, güvenilir, çevre dostu, yerli ve yeşil bir enerji türüdür. Santrallerde, bu enerji dönüştürülerek elektrik elde edilir.

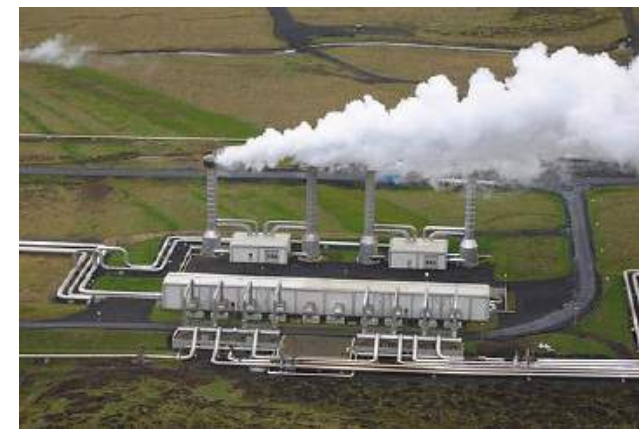

\section{Nükleer Enerji Santrali}

Bir veya daha fazla sayıda nükleer reaktörün yakıt olarak radyoaktif maddeleri kullanarak elektrik enerjisinin üretildiği tesistir. Radyoaktifmaddeler kullanılmasından dolayı diğer santrallerden farklı ve daha sıkı güvenlik önlemlerini, teknolojileri içerisinde barındırır.

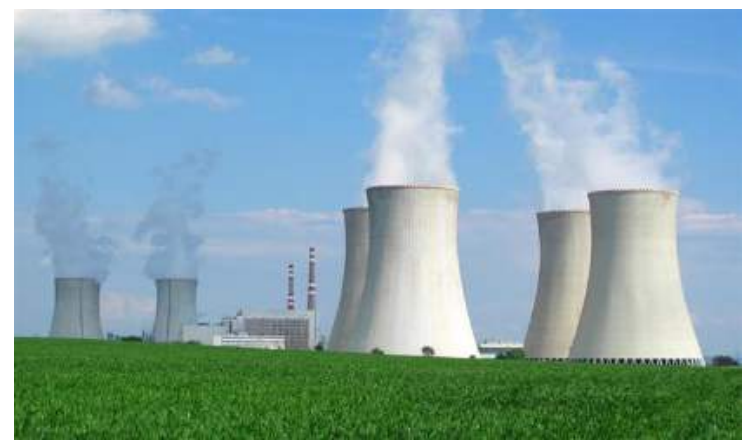

\section{Gel-git Enerjisi}

Denizlerdeki oluşan gelgit olayından yararlanan yenilenebilir birincil enerji kaynağıdır. $\mathrm{Bu}$ enerji türünde gel-git olayı için üretilmiş olan özel türbinler kullanılır. Bu türbinler, iki taraflı olarak hareket edebilirler. Gel-git olayı ile deniz kabarır ve alçalır. Bu iki deniz seviyesi farkından yararlanılarak, türbinler çalışır. Böylece, elektrik üretilir. Gel-git enerjisi için özel türbinlerin yanında, gel-git barajı da gereklidir. Gel-git barajları, köprü gibidir. Altındaki, gel-git türbinleri ile haliçteki gel-git olayı ile elektrik üretilir.

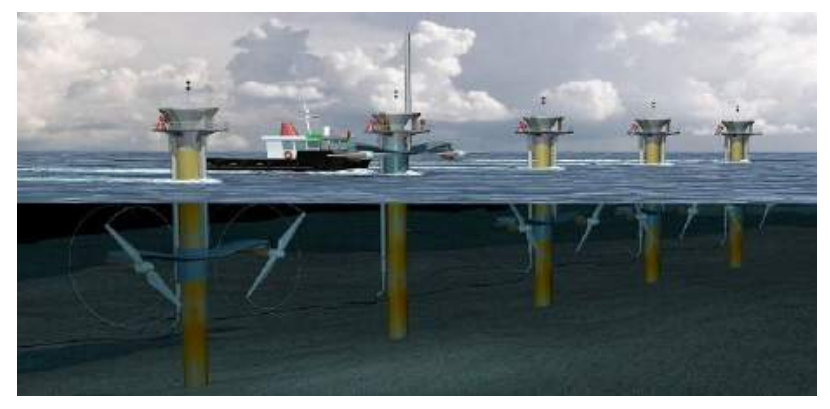


Aylin Çalışkan \& Zeki Özen - Yaratıcı Drama Dergisi 2018, 13(1), 19-36 